\title{
The diversity of phoretic Mesostigmata on Ips typographus (Coleoptera: Scolytinae) caught in the Karkonosze forest
}

\author{
DARIUSZ J. GWIAZDOWICZ ${ }^{1}$, JACEK KAMCZYC ${ }^{1}$ and JERZY BŁOSZYK ${ }^{2}$ \\ ${ }^{1}$ Poznań University of Life Sciences, Department of Forest Protection, Wojska Polskiego 71c, 60-625 Poznań, Poland, \\ e-mail:dagwiazd@up.poznan.pl,jkam@up.poznan.pl \\ ${ }^{2}$ Adam Mickiewicz University, Department of General Zoology, Umultowska 89, 61-614 Poznań, Poland, \\ e-mail: bloszyk@amu.edu.pl
}

Key words. Scolytinae, Ips typographus, mites, Mesostigmata, Dendrolaelaps quadrisetus, Trichouropoda polytricha, phoresis, Karkonosze National Park

\begin{abstract}
This study determined the scale of the phoresy of mesostigmatid mite by Ips typographus. Thirty pheromone traps in the Karkonosze National Park (Poland) caught 10,575 bark beetles on which there were 2,388 mesostigmatid mites belonging to eight species. The most numerous mites were Dendrolaelaps quadrisetus (1076 ind.) and Trichouropoda polytricha (1067 ind.).
\end{abstract}

\section{INTRODUCTION}

Phoresy is defined as the passive transport of certain organisms on the body of others of different species for purposes other than direct parasitization (Rocha et al., 2009). It is also seen as the process by which an animal actively seeks out and attaches to an other animal, for a period of time, in order to disperse to other areas (Holte et al., 2001). Phoresy, as a form of dispersal, is particularly frequent in wingless organisms including mites living in patches of ephemeral resources (Binns, 1982). An ecological and evolutionary advantage of this type of migration, especially for entomophagous phoretic species, is the possibility of colonizing a new food source/host (Clausen, 1976).

Phoresy is recorded for many Gamasida Actinedida and Acaridida mites (Binns 1973, 1982; Athias-Binche, 1993). It is well documented for the mite Uropoda orbicularis on beetles (Coleoptera) associated with cattle dung (Bajerlein \& Błoszyk, 2004) but the information about the phoresy of mesostigmatid mites by bark beetles, in particular forest pests is scarce. Phoresy of mesostigmatid mites on bark beetles bodies is not well investigated and there are only a few records (described as single cases of phoresy) in the faunistic and taxonomic studies of Kiełczewski \& Michalski (1962), Westerboer (1963), Kinn (1971), Bregetova (1977), Eickword (1983), Michalski et al. (1985) and Haitlinger (1991, 2004). However, mites caught in pheromone traps have only been recorded previously by Gwiazdowicz (2007), who records Proctolaelaps fisheri Samšińák on I. typographus body, and there are no reports in which mesostigmatid mite species colonize new habitats by having a phoretic relationship with beetles. This research also has a practical aspect as these beetles are pests of spruce stands in Central Europe and mesostigmatid mites may feed on their eggs and larvae (Kiełczewski \& Michalski, 1962). The spruce bark beetle, Ips typographus (L.) (Coleoptera: Scolytinae), is one of the most important pests of mature Norway spruce trees in Eurasia (Schroeder, 2001). The beetle normally exists at a low level of abundance in all spruce forests but population outbreaks can result in significant economic loss (Feicht, 2004), for example the dead standing trees in Central Europe, Scandinavia and Russia (Faccoli \& Buffo, 2004). In addition, the outbreaks of this pest during 1981 and 1987 in Western Sudeten in Poland resulted in damage to nearly 15,000 ha of spruce forest (Grodzki, 2004).

The main aims of this study were to:

1. confirm that phoresy is the primary method of transport used by mesostigmatid mites to move between the galleries of the bark beetle I. typographus;

2. determine the species diversity of the phoretic mites collected;

3. determine the scale of the death of mites associated with the death I. typographus caught in pheromone traps.

Using pheromone traps to reduce populations of I. typographus can result in the reduction in the abundance of their natural enemies, including mites. Due to the lack of knowledge about the phoresy of mites by bark beetles between galleries and the extensive use of pheromone traps in forestry, there is need to determine the extent of the phoretic relationship between mites and bark beetles.

\section{MATERIAL AND METHODS}

The study area is located in the Karkonosze National Park (SW Poland $-50^{\circ} 44^{\prime} \mathrm{N}, 15^{\circ} 44^{\prime} \mathrm{E}$ ) at an altitude of between 700-800 $\mathrm{m}$ a. s. 1.. Research areas were located close to spruce stands (c.a. 80 years old). Thirty Boregard traps, 6 in each of the 5 study areas, were emptied between 15 and 31 of August 2008 . Traps were located $2 \mathrm{~m}$ from each other $25 \mathrm{~m}$ from the forest boundary. The traps were located in the forest close to the border zone and exposed to direct sunshine (therefore the sunshine was not an experimental factor). A Boregard trap consists of a pipe (length $=135 \mathrm{~cm}, \varnothing=15 \mathrm{~cm}$ ), which contains the commercial attractant Ipsodor W (Chemipan, Poland) (Michalski \& Mazur, 1999). The construction of this trap prevents mites from entering or escaping and so all the mites that were in the traps must have been carried on the bodies of the bark beetles. This study focused mainly on mites and the abundance and sex of the bark beetles were not investigated. A sample consisted of all the bark beetles collected in one Boregard trap and gave a measure of the number of mites killed in one trap. All the bark beetles collected from each trap were placed in $70 \%$ ethanol. Then the mites were collected and placed in $70 \%$ ethanol and later permanent (using Hoyer's medium) or semi-permanent (using lactic acid) slide prepara- 
TABLE 1. The numbers, dominance and frequency of the mesostigmatid species of mites recorded free and on the bodies of Ips typographus caught in the pheromone traps.

\begin{tabular}{|c|c|c|c|c|c|}
\hline Species & Free & On the body & Total & Dominance [\%] & Frequency [\%] \\
\hline Dendrolaelaps quadrisetus & 1059 & 17 & 1076 & 45.06 & 100 \\
\hline Pleuronectocelaeno austriaca & 7 & 2 & 9 & 0.38 & 30 \\
\hline Proctolaelaps fisheri & 55 & 3 & 58 & 2.43 & 40 \\
\hline Trichouropoda polonica & 59 & 1 & 60 & 2.51 & 60 \\
\hline Trichouropoda polytricha & 1009 & 58 & 1067 & 44.68 & 100 \\
\hline Uroobovella obovata & 108 & 7 & 115 & 4.82 & 93.3 \\
\hline Halolaelaps sp. & 1 & & 1 & 0.04 & 3.3 \\
\hline Uroobovella sp. & 2 & & 2 & 0.08 & 6.6 \\
\hline Total & 2300 & 88 & 2388 & 100.00 & 30 \\
\hline
\end{tabular}

tions of the mites were made, the number of mites counted and identified using the latest taxonomical literature.

The zoocenological analysis of mesostigmatid mite communities was based on indices of dominance (D) and frequency (F) (Błoszyk, 1999). Dominance classes were classified as follows: eudominants (>30\%); dominants $(15.01-30 \%)$; sub-dominants $(7.01-15.0 \%)$; residents $(3.01-7 \%)$ and subresidents $(<3 \%)$. For frequency the following criteria were used: euconstants (> 50\%); constants $(30.01-50 \%)$; subconstants $(15.01-30 \%)$; accessory species $(5.01-15 \%)$ and accidental occurrences $(<5 \%)$. Numbers of bark beetles collected per sample and of mites collected from a trap are given as means with standard deviation.

\section{RESULTS}

10575 bark beetles were examined for phoretic mesostigmatid mites and eight mite species were identified. The number of bark beetles collected per sample ranged from 76 to 861 and the average number was $352.5 \pm 207$. In total 2,388 mites were caught (Table 1). The number of mites collected from a trap varied from 8 to 326 and the average number was $77.33 \pm 77$. The mean number of mites per 100 bark beetles per sample was 23.

Overall, Dendrolaelaps quadrisetus was the most numerous species (1076 ind.), followed by Trichouropoda polytricha (1067 ind.). Other species e.g. Urobovella obovata (115 ind.), Proctolaelaps fisheri (58) and Trichouropoda polonica (60) occurred in lower numbers. Two species, Pleuranectocelaneo austriaca and Urobovella sp. were recorded sporadically at very low densities, nine and two individuals, respectively.

Dendrolaelaps quadrisetus $(D=45.06)$ and Trichouropoda polytricha $(D=44.68)$ were classified as eudominants. Residents were represented by Urobovella obovata $(D=4.82)$. Other species occurred in lower numbers and were classified as sub-residents. Dendrolaelaps quadrisetus and Trichouropoda polytricha were classified as euconstants with a frequency of $F$ $=100$. Pleuranectocelaneo austriaca, Proctolaelaps fisheri and Trichouropoda polonica are constant species, and Halolaelaps sp. and Urobovella sp. an accidental occurrence.

\section{DISCUSSION AND CONCLUSIONS}

Under the bark, I. typographus is accompanied by a speciesrich arthropod community. In Europe, about 140 species of Coleoptera, Diptera, Hymenoptera and other orders have been recorded in trees attacked by I. typographus (Hedgen \& Schroeder, 2004). Thus far, almost 60 species of mesostigmatid mites have also been found in the galleries of I. typographus (Gwiazdowicz, 2008). The most numerous and most frequently represented families are the Ascidae, Digamasellidae and Trematuridae. It may be hypothesized that they reach the gal- leries by means of phoresy on bark beetles. However, there is little information concerning the phoretic relationships between I. typographus and mesostigmatid mites. It is noteworthy that Gwiazdowicz (2007) found Proctolaelaps fisheri Samšiňák on this species of bark beetle. Research on other bark beetle species, however, indicates the existence of phoretic relationships with mites. Kiełczewski \& Michalski (1962) found Lasioseius ometes (Oudemans) on the body of Scolytus mali (Bechstein), Westerboer (1963) Proctolaelaps eccoptogasteris (Vitzthum) on the body of Scolytus laevis Chapuis, Kinn (1971) Lasioseius on the body of Ips mexicanus (Hopkins), Bregetova (1977) records phoretic Pleuronectocelaeno austriaca Vitzthum on Scolytus laevis and Michalski et al. (1985) found this species on the elytra of Pityokteines curvidens (Germar) and Ips acuminatus (Gyllenhal). Mites of the genera Lasioseius and Proctolaelaps were found by Eickword (1983) on bodies of many bark beetle species. Haitlinger $(1991,2004)$ observed Proctolaelaps fisheri on bodies of Pityokteines curvidens, Dryocetes autographus (Ratzeburg), Rosalia alpina (L.) and Spondylis buprestoides (L.).

Almost all these mites are recorded exclusively from bark beetle galleries. D. quadrisetus, for instance, is recorded in galleries of many Scolytinae species in Europe, North America (Canada, Guatemala, USA) and North Africa. T. polytricha is recorded in Europe and Central Asia (Hirschmann \& Wiśniewski, 1982; Wiśniewski \& Hirschmann, 1993). Other species are reported from Europe, North Africa and USA (Wiśniewski \& Hirschmann, 1993; Gwiazdowicz, 2007, 2010). $U$. obovata is an exception as it is more frequently found in ant nests than in bark beetle galleries (Wiśniewski \& Hirschmann, 1993). So far, this species has been recorded only in Europe.

Different developmental stages of the mites are phoretic. For instance in D. quadrisetus and mites of the suborder Uropodina (T. polytricha, T. polonica, U. obovata, U. sp.), only deutonymphs, while in other species only adults, both females and males, were found in the traps. That phoresy is the primary method of dispersal used by mesostigmatid mites is indicated by the large number of phoretic mites found on bark beetles. However, the small number of species of mite recorded in this study, which is probably related to the specificity of local populations, is surprising. It is likely that the communities of phoretic mites are different in other regions of Europe.

In conclusions, the use by forest managers of Boregard traps to catch Ips typographus might result in the extermination of mesostigmatid mites, which are considered to be important natural enemies of this forest pest.

ACKNOWLEDGEMENTS. The authors would like to thank the Karkonosze National Park Management for help in collecting material and S.J. Coulson at the University Centre in Svalbard, 
Longyearbyen, Norway for help with the English. This study was prepared within the framework of a grant from the Ministry of Science no. NN 309070736.

\section{REFERENCES}

AthiAs-Binche F. 1993: Dispersal in varying environments: the case of phoretic uropodid mites. Can. J. Zool. 71: 1793-1798.

Bajerlein A. \& BŁoszyK J. 2004: Phoresy of Uropoda orbicularis (Acari: Mesostigmata) by beetles (Coleoptera) associated with cattle dung in Poland. Eur. J. Entomol. 101: 185-188.

BINNS E.S. 1973: Digamasellus fallax Leitner (Mesostigmata: Digamasellidae) phoretic on mushroom sciarid flies. Acarologia 15: 10-17.

Binns E.S. 1982: Phoresy as migration - some functional aspects of phoresy in mites. Biol. Rev. 57: 571-620.

BŁosZYK J. 1999: Geograficzne i Ekologiczne Zróżnicowanie Zgrupowań Roztoczy z Kohorty Uropodina (Acari: Mesostigmata) w Polsce. I. Uropodina Lasów Gradowych (Carpinion betuli). Geographic and Ecological Diversity of Cohort Uropodina Mites Communities (Acari: Mesostigmata) in Poland. I. Uropodina of Oak-hornbeam Forests (Carpinion betuli). Wydawnictwo Kontekst, Poznań, 245 pp.

Bregetova N.G. 1977: Kohorta Antennophorina. In Gilarov M.C. \& Bregetova N.G. (eds): Opredelitel Obitayuschikh v Pochve Kleshchey - Mesostigmata. [Key for Identification of Soil Mites - Mesostigmata.] Nauka, Leningrad, pp. 39-43.

Clausen C.P. 1976: Phoresy among entomophagous insects. Annu. Rev. Entomol. 21: 343-368.

EICKWORT G.C. 1983: Potential use of mites as biological control agents of leaf-feeding insects. In Hoy M.A. \& Cunningham G.L. (eds): Biological Control of Pests by Mites. University of California Press, Berkeley, pp. 41-52.

FACCOLI M. \& Buffo E. 2004: Seasonal variability of sex-ratio in Ips typographus (L.) pheromone traps in a multivoltine population in the Southern Alps. J. Pest Sci. 77: 123-129.

Feicht E. 2004: Parasitoids of Ips typographus (Col., Scolytidae), their frequency and composition in uncontrolled and controlled infested spruce forest in Bavaria. J. Pest Sci. 77: $165-172$.

GrodzKi W. 2004: Some reactions of Ips typographus (L.) (Col.: Scolytidae) to changing breeding conditions in a forest decline area in the Sudeten Mountains, Poland. J. Pest Sci. 77: 43-48.

Gwiazdowicz D.J. 2007: Ascid Mites (Acari, Mesostigmata) from Selected Forest Ecosystems and Microhabitats in Poland. Wydawnictwo Akademii Rolniczej, Poznań, 248 pp.

Gwiazdowicz D.J. 2008: Mesostigmatid mites (Acari) associated with Scolytidae in Poland. In Gwiazdowicz D.J. (ed.): Selected Problems of Acarological Research in Forests. Wydawnictwo Uniwersytetu Przyrodniczego, Poznań, pp. 59-95.

Gwiazdowicz D.J. 2010: Sejoidea, Antennophoroidea, Celaenopsoidea, Microgynioidea (Acari, Mesostigmata) of Poland. Bogucki Wydawnictwo Naukowe, Poznań, 142 pp.
Haitlinger R. 1991: List of mites occurring on insects in Poland. Wiadom. Parazytol. 37: 85-90.

Haitlinger R. 2004: Mites (Acari) occurring on some Coleoptera (Insecta) in Poland. Pol. Pis. Entomol. 73: 3-24.

Hedgren P.O. \& Schroeder L.M. 2004: Reproductive success of the spruce bark beetle Ips typographus (L.) and occurrence of associated species: a comparison between standing beetlekilled trees and cut trees. Forest Ecol. Manag. 203: 241-250.

HiRsChMANN W. \& WiśnIEWSKI J. 1982: Weltweite Revision der Gattungen Dendrolaelaps Halbert 1915 und Longoseius Chant 1961 (Parasitiformes). Acarologie 29 (I): 1-190, (II): 1-48.

Holte A.E., Houck M.A. \& Collie N.L. 2001: Potential role of parasitism in the evolution of mutualism in astigmatid mites: Hemisarcoptes cooremani as a model. Exp. Appl. Acarol. 25: 97-107.

KietcZewski B. \& Michalski J. 1962: Wpływ roztoczy (Acarina) na gęstość populacji ogłodków (Scolytinae). [Impact of mites (Acarina) on the density of bark beetle population (Scolytinae).] Zesz. Probl. Postep. Nauk Roln. 35: 133-135.

KINN D.N. 1971: The life cycle and behavior of Cercoleipus coelonotus (Acarina: Mesostigmata). Including a survey of phoretic mite associates of California Scolytidae. Univ. Calif. Publ. Entomol. 65: 1-62.

Michalski J. \& Mazur A. 1999: Korniki. Praktyczny Przewodnik dla Leśników. [Bark Beetles. A Practical Guide for Foresters.] Wydawnictwo Świat, Warszawa, 188 pp.

Michalski J., Ratajczak E. \& Wiśniewski J. 1985: Roztocze (Acarina: Mesostigmata) towarzyszące kornikom (Coleoptera: Scolytidae) Gór Świętokrzyskich. [Mites (Acarina: Mesostigmata) associated with Bark Beetles (Coleoptera: Scolytidae) in the Swietokrzyskie Mountains.] PTPN, Prace Komisji Nauk Rolniczych i Komisji Nauk Leśnych 60: 85-92.

Rocha S.L., Pozo-Velazquez E., Faroni L.R. \& Guedes R.N. 2009: Phoretic load of the parasitic mite Acarophenax lacunatus (Cross \& Krantz) (Prostigmata: Acarophenacidae) affecting mobility and flight take-off of Rhyzopertha dominica (F.) (Coleoptera: Bostrichidae). J. Stor. Prod. Res. 45: $267-271$.

SCHROEDER L.M. 2001: Tree mortality by the bark beetle Ips typographus (L.) in storm-disturbed stands. Integr. Pest Manag. 6: 169-175.

Westerboer I. 1963: Die Familie Podocinidae Berlese 1916. In: Stammer H.J. (ed.): Beitrage zur Systematik und ökologie mitteleuropäischer Acarina. II. Mesostigmata. Akademische Verlagsgesellschaft Geest \& Portig K.-G., Leipzig, pp. 179-450.

WiŚNIEWSKI J. \& HiRSChMANN W. 1993: Katalog der Ganggattungen, Untergattungen, Gruppen und Arten der Uropodiden der Erde (Taxonomie, Literatur, Grösse, Verbreitung, Vorkommen). Acarologie 40: 1-220.

Received September 23, 2010; revised and accepted February 9, 2011 